Dr Ivana Mitrović Đorđević

defektolog - logoped, defektolog - surdopedagog

OŠ ,Dušan Dugalić”, Beograd
Original scientific paper

UDK: 371.382

DOI: $10.5937 /$ IstrPed2101328M

\title{
(NE)ZAVISNOST OD IGRANJA VIDEO-IGARA IZ PERSPEKTIVE UČENIKA NIŽIH RAZREDA OSNOVNE ŠKOLE
}

\begin{abstract}
Rezime: Predmet istraživanja čije rezultate donosimo u ovome radu jesu stavovi učenika o igranju video-igara. Istraživanje je sprovedeno sa primarnim ciljem da se utvrdi odnos učenika četvrtog razreda osnovne škole prema igranju videoigara i konstatuje njihov stav o sopstvenoj (ne)zavisnost od igranja video-igara, kao podvrste zavisnosti od interneta. $U$ istraživanju su učestvovali učenici više odeljenja dve beogradske osnovne škole (ukupno: 121 ispitanik), koji su popunili jedan od standardizovanih upitnika, preuzet iz relevantne literature. Analizom dobijenih rezultata potvrđena je polazna hipoteza istraživanja: Učenici četvrtog razreda osnovne škole ne smatraju da su zavisni od igranja video-igara. Prema mišljenjima koja dominiraju, učenici uključeni u istraživanje nemaju izražene potrebe da provode više vremena u igranju video-igara, nisu primetili kod sebe promenljivo ili problematično ponašanje uzrokovano ovom vrstom aktivnosti, kao ni fizičke smetnje prilikom smanjivanja ili prekidanja samog igranja. Takođe, ne smatraju da su narušili socijalne odnose (sa porodicom i prijateljima) ili zanemarili školske i kućne obaveze i interesovanja. Samo ispitivanje i dobijeni rezultati otvorili su pitanja i za buduća promišljanja istraživane oblasti.
\end{abstract}

Ključne reči: internet, nove tehnologije, učenici osnovnih škola, video-igra, zavisnost.

\section{Uvod}

Internet, masovna primena informaciono-komunikacionih tehnologija, robotizacija i automatizacija danas snažno utiču i menjaju sve sfere ljudskog života, vodeći ga, kako O. N. Četverikova (rus. О. Н. Четверикова) upozorava, ,u posthumano biće puno različitih čipova, kiborg svesti, integrisano u svetsku informacionu mrežu" (Cetverikova, 2020). Sve je više naslova (Carr, 2010; Schwab, 2016; Votson, 2016) kojima se apostrofira da su internet ${ }^{2}$ i digitalizacija doneli svojevrsno preoblikovanje čoveka (Prtljaga i Dordev, 2020: 336). Sâm L. Klajnrok (L. Kleinrock), jedan od tvoraca interneta, smatra da je „Internet izrodio i neželjene pojave”, ali, istovremeno, ,uveren je da njegove pozitivne strane nadmašuju one loše”, ističući pritom „da smo neke od tih [negativnih] stvari mogli da sprečimo” (prema: Prtljaga, 2012: 702). Jedna od vodećih negativnih pojava povezanih sa upotrebom interneta jeste i tzv. nova

\footnotetext{
${ }^{1}$ mitrovicdjordjevic@gmail.com

${ }^{2}$ Više o istorijatu razvitka interneta, te internet sajtovima danas v. Prtljaga i Bratina (2020: 19-34).
} 
bolest ${ }^{3}$ - zavisnost od interneta / internet zavisnost (engl. internet addiction) (Gu et al., 2018: 39-48; Masi et al., 2020).

Zavisnost ${ }^{4}$ od interneta je klinički poremećaj sa snažnim negativnim posledicama na socijalno, radno, porodično, finansijsko i ekonomsko funkcionisanje ličnosti. Ona predstavlja savremen oblik zavisnosti koji se manifestuje kao stanje pojedinca u kome je upotreba interneta postala dominantna životna aktivnost koja ga izoluje u odnosu na ostale društvene tokove, i koja stvara negativne posledice po njega i njegovu okolinu. Zavisnost o interneta, kao i zavisnost od medija, televizije, mobilnih telefona ubraja se u tehnološke zavisnosti (Griffiths \& Hunt, 1995: 189-193). Pojedinci zavisnici od interneta pokazuju određene obrasce ponašanja kao što su: a) preterano razmišljanje o internetu, b) postepeno povećanje nivoa zadovoljstva proisteklog iz upotrebe interneta, c) neuspeh u pokušajima smanjenja štete od korišćenja interneta, č) bes i razočaranje kao rezultat podvrgavanja ovim pokušajima, d) povećanje vremena provedenog na internetu, dž) problemi u socijalnim i profesionalnim odnosima zbog korišćenja interneta i e) radije pribegavanje upotrebi interneta nego rešavanju ili suočavanju sa problemima (Young, 1998: 237-244).

\subsection{Vrste zavisnosti od interneta}

Pojam zavisnost od interneta / internet zavisnost (internet addiction) prvi put je upotrebljen 1996. godine, a ubrzo zatim počinju da se otvaraju prve institucije specijalizovane za ovaj problem; danas ih ima u čitavom svetu. ${ }^{5}$ Zavisnost od interneta ispoljava se u više oblika: a) zavisnosti od igranja video-igara; b) zavisnost od surfovanja internetom; c) zavisnost od sajberseksa; č) zavisnost od uspostavljanja prijateljskih veza putem interneta; ć) zavisnost od internet kockanja; d) zavisnost od računara uopšte. Kao što se može videti, zavisnost od igranja video-igara, koja je u fokusu ovoga rada, jeste na prvom mestu kada govorimo o oblicima zavisnosti od interneta. U prilog rečenom je i sledeća primedba: „Korisnici interneta u centrima za video-igre ponekad padnu u nesvest od iscrpljenosti i manjka vode u organizmu umeju danima da igraju igre na internetu, i pritom nedovoljno jedu i neredovno spavaju. Ovde takve klubove, tzv. igraonice, zovemo i 'pušionice opijuma 21. veka"' (Yeonsoo et al., 2010: 5157, grafičko isticanje I. M. Đ.). Igranje video-igara smatra se, dakle, aktivnošću koja se može povezati sa zavisnim ponašanjem. lako je dijagnoza zavisnosti od igranja video-igara prihvaćena i uvrštena među bolesti zavisnosti, još se ispituju određene specifičnosti ovog poremećaja (Griffiths, 2017: 59-63; Milani et al., 2017: 888-904; Zastrow, 2017: 4268-4272), između ostalog i znaci zavisnosti od interneta.

\footnotetext{
3 Psiholozi i psihijatri su podeljeni (up. Fischer, 2011: 82-84) - neki podržavaju plimu ustanova za tretman nove vrste 'bolesti', ali ima i lekara koji tvrde da problem nije medicinske prirode i da dugo sedenje pred računarom ne treba ni smatrati bolešću (Cheng \& Liu, 2020: 2370 ; Wakefield \& Rice, 2008). Videti i: Rumpf, Batra, Mann (2014: 364-366), kao i Te Wildt (2011: 80-82).

${ }^{4}$ Zavisnost se definiše kao želja koja se ne može sprečiti i koja se javlja kao rezultat konstantnog uzimanja određene supstance u sve većim dozama bez namere da se iskorene simptomi organske bolesti (Ziyalar, 1999, prema Zorbaz, Ulas, \& Kizildag, 2015: 490) Pojmovi zavisnost i zavisno ponašanje poseduju zajedničku karakteristiku, a to je „nemogućnost da se kontroliše radnja koja se ponavlja uprkos izazivanju loših rezultata" (Henderson, 2001).

${ }^{5}$ Primera radi, zdravstvena služba u Kini smatra šest sati neprekidnog korišćenja računara za granicu posle koje neko može da bude klasifikovan kao 'zavisnik' i biti upućen na lečenje. Vlada u Seulu je prihvatila da je zavisnost od interneta ozbiljan zdravstveni problem u zemlji - otvorila je savetovališta i pokrenula programe prevencije, ali rezultati su ograničeni, jer se kultura interneta nezadrživo širi pre svega među mladima (Di et al., 2019; Yeonsoo et al., 2010: 51-57). Itd.
} 


\subsection{Znaci zavisnosti od interneta i igranja video-igara}

Vreme provedeno za računarom ${ }^{6}$ je najčešće pominjani kriterijum za dijagnostifikovanje poremećaja zavisnosti od interneta (Brunborg, Mentzoni, \& Froyland, 2014: 27-32; Festl, Scharkow, \& Quandt, 2013: 592-599; Triberti et al., 2018: 185-188). Tako, na primer, prema rezultatima istraživanja sprovedenog 2013. godine, stanovnici u Hrvatskoj uz video-igre provedu prosečno 612 sati godišnje, odnosno na neprekidnog igranja video-igara (bez pauza za jelo, piće, spavanje i ostale svakodnevne potrebe) odlazi oko 25 dana (Tvornica istraživanja, 2014, prema Labas, Marinsis, Mujcinovic, 2019: 9). Međutim, još nije precizno utvrđeno da li vreme provedeno u igranju video-igara treba posmatrati kao pouzdani simptom zavisnosti ili ne, odnosno ono može ali i ne mora biti pokazatelj zavisnosti.7 Mnogo sigurniji znaci zavisnosti od igranja video-igara, te i interneta uopšte su: promenjeno ponašanje, prekid školovanja ili radnog odnosa, zanemarivanje drugih obaveza i interesovanja, problemi sa koncentracijom i pamćenjem, nesanica, problemi sa kičmom, vidom, sluhom. i dr. ${ }^{8}$ Simptomi apstinencijalne krize, tj. kad se zavisnicima uskrati korišćenje interneta, mogu biti različiti, među ostalima su i ,razdražljivost, gnev, poremećen ciklus sna” (Plante et al, 2019: 385-394; Scimeca et al., 2018: 92-97). J. Blok (Jerald Block) primećuje „,kad ljudi koriste internet igrajući igre 30, 40 ili 50 sati nedeljno, oni ga koriste iz tri razloga: 1. pre svega je reč o usmeravanju pažnje, načinu da se provodi vreme; 2 . korisnici time prazne svoju agresiju i druge impulse; 3. uloga računara je da pravi korisniku društvo" (Block, 2008). Blok dodaje da korisnik formira sa računarom odnos kao sa drugom osobom i da onog trenutka kad mu roditelj ili nadređeni isključi računar, korisnik gubi tri stvari odjednom, te stoga preporučuje da se lečenju ove zavisnosti priđe izuzetno oprezno.

\subsection{Zavisnost od interneta i mladi}

Ponekad mladi, pre svega tinejdžeri, pokušaju da zamene pravi društveni život za onlajn društveni život. Tokom komunikacije sa ljudima na internetu, mogu se smanjiti osećaji nesigurnosti i usamljenosti kod rizičnih grupa (Tras, 2019: 465-473). Međutim, ceo taj proces

\footnotetext{
${ }^{6}$ Pod vremenom provedenim na internetu u obzir se uzima kako vreme onlajn boravka na mreži, tako i sve ostale aktivnosti koje su u vezi sa mrežom - pisanje elektronske pošte, čitanje preuzetih vesti, časopisa, članaka, tekstova uopšte i dr.

7 Tako, na primer, Triberti i saradnici smatraju (Triberti et al., 2018: 185-188) da je šest sati neprekidnog korišćenja računara granica posle koje neko može da bude klasifikovan kao 'zavisnik'. S obzirom na to da se danas sve više poslova odvija onlajn, pogotovo kada se u obzir uzme aktuelna situacija izazvana pandemijom Covida-19, ovo vremensko određenje treba uzeti sa rezervom, jer je obično da samo radni dan (danas često u onlajn okruženju) traje 8 sati, odnosno uvek je iznad navedene granice. Tome treba dodati svakako zapažanje da se zavisnost od video-igara povećava kako se povećava ukupno vreme provedeno na računaru.

${ }^{8} \mathrm{~K}$. Greogori (C. Gregory) razlikuje sledeće simptome zavisnosti i izdvaja pritom i neka od pitanja kojima se oni mogu (samo)dijagnostifikovati: a) gubljenje pojma o vremenu (Da li često zatičete sebe na internetu duže nego što ste planirali? Da li se nekoliko minuta pretvara u nekoliko sati? Da li postajete nervozni kada se vaše vreme onlajn prekida?); b) problemi sa izvršavanjem zadataka kod kuće ili na poslu. (Da li vam se skupljaju obaveze zbog toga što provodite previše vremena onlajn? Možda čak koristite internet kada svi odu na spavanje, kako biste imali više slobode?); c) izolacija od prijatelja i porodice (Da li vaš socijalni život pati zbog interneta? Da li ignorišete prijatelje i porodicu? Da li se osećate kao da vas niko ne razume u „stvarnom svetu"?); č) osećanje krivice zbog upotrebe interneta (Da li vam je dosta prigovaranja roditelja/prijatelja da ostavite računar? Da li lažete druge o svojoj upotrebi interneta i krijete svoje onlajn aktivnosti?); osećanje euforije pri upotrebi interneta (Da li koristite internet kada ste tužni, umorni, nesrećni ili kada hoćete da budete srećniji nego što već jeste? Da li ste (neuspešno) pokušavali da ograničite svoju upotrebu interneta?) itd. (Gregory, 2019).
} 
vodi u još dublju izolaciju, nakon čega se mladi zavisni od interneta počinju najviše fokusirati na svoje onlajn odnose. Zavisnost od interneta je mnogo više od čestog proveravanja naloga na društvenim mrežama. Ova vrsta zavisnosti uključuje toliko jaku želju mladih, u najvećoj meri tinejdžera, da bude 'onlajn', da im to ometa svakodnevni život. Sve ovo, dalje vodi u društvene i akademske probleme jer onlajn ponašanje tinejdžera počinje da ga sprečava u obavljanju dnevnih obaveza. Mlade osobe (tinejdžeri) koji su zavisni od interneta, osim što provode znatan broj sati na internetu, konstantno i razgovaraju o utiscima nakon toga; odbijaju da učestvuju u društvenim aktivnostima kako bi proveli više vremena 'onlajn'9; događaju im se izlivi besa, anksioznost, ili frustracije ako im se zabrani korišćenja interneta; uvek nanovo koriste internet bez obzira na probleme koje to izaziva u školi ili društvenim odnosima (Zorbaz, Ulas, Kizildag, 2015: 489-497). Takođe, postoje fizički i zdravstveni indikatori koji se javljaju: problemi sa zdravljem kao što su glavobolje i bolovi u leđima; problemi sa spavanjem; problemi sa vidom i suve oči; gubitak kilaže i izbegavanje obroka zbog korišćenja interneta; loša higijena (Di et al., 2019). Sve navedene simptome/indikatore potencijalne zavisnosti od interneta i ,zarobljavanja u virtuelnom svetu”, pogotovo u virtuelnim društvenim odnosnima, treba na vreme prepoznati i dalje, prema stepenu zavisnosti, delovati/lečiti. Primećuje se da pojedinci između 8 i 18 godina imaju najveći rizik pada u zavisnost od video-igara. Igranje video-igara doseže vrhunac u uzrastu između 8. i 15. godine (Walsh, 2005, prema Bilic, Gjukic, Kirinic, 2010: 207). No potrebno je napomenuti da se ta granica proširuje sve češće i na odraslo doba. lako su pokazatelji zabrinjavajući, važno je naglasiti da svi igrači ne razviju zavisnost.

Istraživanje predstavljeno 2017. godine na konferenciji „Medijski odgoj i zaštita dječjih prava” u Zagrebu, pokazalo je da deca koja igraju video-igre navode da ih najčešće igraju svakodnevno (39,4\%), a približno je jednak broj dece je odgovorio da video-igre igra 2 do 3 puta nedeljno $(31,2 \%)$ ili samo vikendom $(29,4 \%)$. lako polovina ispitane dece video-igre igra manje od jedan sat dnevno, rezultati su ukazali na to kako ipak postoji manja rizična grupa od $4,5 \%$, što čini jedan prosečan razred od 25 učenika, među ispitanicima u tri škole, koji provode više od tri sata dnevno igrajući video-igre. Pritom navode kako igraju od tri pa do čak šest sati dnevno bez prekida, a neki i celi dan (Kuzmanovic, Pavlovic, Popadic i Milosevic, 2019).

V. Bilić, D. Gjukić i G. Kirinić ukazuju na istraživanju Grifitsa i saradnika (Griffiths et al., 1995, prema Bilic, Gjukic, Kirinic, 2010: 207), u kojem je učestvovalo 816 dece između 10 i 16 godina utvrđeno je da njih 5, 7\% pokazuje karakteristike zavisnosti. Tri godine kasnije isti autor sproveo je istraživanje u kojem je učestvovalo 387 dece od 12 do 16 godina, a rezultati pokazuju da njih $20 \%$ pokazuje simptome zavisnosti. U sličnom istraživanju Nacionalnog instituta za medije i porodicu, u kojem je učestvovalo 607 učenika osmog i devetog razreda, njih 15\% sebe opisuje kao zavisnike (Hague \& Gentle, 2003, prema Bilic, Gjukic, Kirinic, 2010: 207).

Ako fokus s tinejdžera usmerimo na decu, može se primetiti da se u današnje vreme neretko dešava da se i tradicionalne dečje igre zamenjuju naprednim video-igrama. Video-igre predstavljaju osnov digitalne pismenosti dece, i nju treba razvijati još od predškolske dobi, a njihova prednost $u$ odnosu na tradicionalne igre ogleda se u novom pristupu učenju i brzom sticanju informacija. Igrajući video-igre, deca nisu ni svesna da uče. Međutim, koliko god da

\footnotetext{
9 Istraživanje rađeno 2020. godine u Španiji, na uzorku od 1502 ispitanika od 11 do 19 godina pri tome pokazuje da mladi vikendom provode više vremena igrajući video-igre nego radnim danima. Dečaci provedu više vremena igrajući nego devojčice. Devojčice više vole edukativne igre koje igraju na tabletu i mobilnom telefonu, a dečaci akcione, sportske, strateške koje igraju na PS ili konzolama (GomezGonzalvo, Molina, \& Devis-Devis, 2020).
} 
učenje na ovaj način, s jedne strane, ima prednosti i u skladu je sa digitalnim dobom u kome živimo, s druge - može imati itekako negativnih posledica. Do nepoželjnih posledica videoigara dolazi kada zbog igranja video-igara dete zapostavi svoj odnos prema porodici (Venkatesh et al. 2019: 903-927), školi, drugarima, ishrani, spavanju...

Imajući u vidu sve prethodno rečeno, izgleda veoma izazovno ispitati šta o igranju video-igara, internet zavisnosti i sl. misle mladi - po M. Prenskom (engl. Marc Prensky) „digitalni urođenici" (Prensky, 2001: 1-6), kojima su video-igre, imejl, internet, mobilni telefoni i neposredna razmena poruka integralni deo života.

\section{Metodološki okvir}

Predmet ovog (eksplorativnog) istraživanja čije rezultate donosimo u nastavku jesu stavovi učenika o igranju video-igara. Istraživanje je sprovedeno sa primarnim ciljem da se utvrdi odnos učenika četvrtog razreda osnovne škole prema igranju video-igara i konstatuje njihov stav o potencijalnoj sopstvenoj (ne)zavisnost od igranja video-igara. Primarna hipoteza istraživanja jeste: Učenici četvrtog razreda osnovne škole ne smatraju da su zavisni od igranja video-igara. Uzorak istraživanja je prigodni - uzorkom je obuhvaćen 121 ispitanik, a ispitanici su učenici tri odeljenja četvrtog razreda Osnovne škole „Siniša Nikolajević”, Beograd (72) i učenici dva odeljenja Osnovne škole „Bora Stanković” (49), takođe iz Beograda (opis uzorka prema polnoj pripadnosti v. u Tabeli 1). Istraživanju je prethodila kratka diskusija o pojmu zavisnosti i zavisnom ponašanju ( $v$. fn 3 ).

Tabela 1. Uzorak istraživanja prema polu Pol ispitanika

\begin{tabular}{|l|l|l|l|}
\hline Muški & Ženski \\
\hline Broj & Procentualna zastupljenost & Broj & Procentualna zastupljenost \\
\hline 57 & $47.11 \%$ & 64 & $52.89 \%$ \\
\hline
\end{tabular}

Merni instrument. Za potrebe prikupljanja podataka korišćen je upitnik sa minimalno modifikovanom skalom procene, ekscerpiran iz knjige sa terapijskim priručnikom dr Gorana Lažetića i dr Ivice Mladenovića „Izgubljeni u virtuelnom svetu”, sa podnaslovnom odrednicama: „Zavisnost od interneta i video igara” (2014, Beograd: Čigoja štampa). Ovaj instrument je usklađen sa procenom načina korišćenja video-igara u porodicama koje upravljaju medijima (v. The Video Game Addiction Questionnaire, Gentile, 2006). Upitnik se sastoji iz 10 sugestivnih pitanja, na koje se odgovara izborom na skali procene, i to od 1 (skoro nikad) do 5 (skoro uvek). ${ }^{10}$ Prikupljeni podaci obrađeni su analitičkom i deskriptivnom metodom, a propraćeni kratkim diskusijama, s obzirom na problematiku pokrenutu određenim pitanjima. Svako od 10 pitanja navedeno je (u izvornom obliku) u zaglavlju posebnih tabela (isp. niže tabele $2-11$ ).

\section{Rezultati i diskusija}

Na prvo pitanje u upitniku Da li ste primetili da više trošite vremena razmišljajući o igranju videoigara, učenju taktika za igranje video-igara ili planiranje sledeće prilike da igrate?, kako pokazuje Tabela 2, trećina ispitanika (30,58\%) odgovorila je da to čini ponekad, a retko $23,14 \%$, čak 22,3\% ispitanika tvrdi da to ne čini skoro nikada.

\footnotetext{
${ }^{10}$ Originalni upitnik (v. Lažetić i Mladenović, 2014) sadrži skalu procene od 1 do 3, ovde je, zarad dobijanja preciznijih odgovora, ona modifikovana u skalu od 1 do 5 .
} 
Tabela 2. Vreme posvećeno planiranju i/ili učenju video-igara iz perspektive učenika

1. Da li ste primetili da više trošite vremena razmišljajući o igranju video-igara, učenju taktika za igranje video-igara ili planiranje sledeće prilike da igrate?

\begin{tabular}{|l|l|l|l|l|l|l|}
\hline Odgovori & Skoro nikad & Retko & Ponekad & Često & Skoro uvek & Ukupno \\
\hline Broj & 27 & 28 & 37 & 16 & 13 & 121 \\
\hline $\begin{array}{l}\text { Procentualna } \\
\text { zastupljenost }\end{array}$ & $22.3 \%$ & $23.14 \%$ & $30.58 \%$ & $13.22 \%$ & $10.74 \%$ & $100 \%$ \\
\hline
\end{tabular}

Drugo pitanje bilo je fokusirano na emocionalni odnos prema igranju video-igara. Na pitanje Da li imate potrebu da provedete više vremena kako biste igrali video-igre i osetili uzbuđenje, trećina ispitanika je odgovorila da skoro nikada nema takvu potrebu (33,88\%), v. Tabelu 3. Nasuprot tome, skoro uvek više vremena posvećuje igranju video-igara da bi osetili uzbuđenje, svega $7,44 \%$ ispitanika.

Tabela 3. Video-igre vs uzbuđenje iz ugla učenika

2. Da li imate potrebu da provedete više vremena kako biste igrali video-igre i osetili uzbuđenje?

\begin{tabular}{|l|l|l|l|l|l|l|}
\hline Odgovori & Skoro nikad & Retko & Ponekad & Često & Skoro uvek & Ukupno \\
\hline Broj & 41 & 31 & 29 & 11 & 9 & 121 \\
\hline $\begin{array}{l}\text { Procentualna } \\
\text { zastupljenost }\end{array}$ & $33.88 \%$ & $25.62 \%$ & $23.97 \%$ & $9.09 \%$ & $7.44 \%$ & $100 \%$ \\
\hline
\end{tabular}

Odgovarajući na pitanje broj 3, najviše ispitanika je istaklo da skoro uvek (31,40\%) pokušava da vremenski kraće ili ređe igra video-igre (v. Tabelu 4). Nasuprot tome, skoro nikada to ne čini svega $14,05 \%$ ispitanika.

Tabela 4. Učenici o smanjenu učestalosti i dužine igranja video-igara

3. Da li ste pokušavali da vremenski kraće ili ređe igrate video-igre?

\begin{tabular}{|l|l|l|l|l|l|l|}
\hline Odgovori & Skoro nikad & Retko & Ponekad & Često & Skoro uvek & Ukupno \\
\hline Broj & 17 & 25 & 19 & 22 & 38 & 121 \\
\hline Procentualna zastupljenost & $14.05 \%$ & $20.66 \%$ & $15.71 \%$ & $18.18 \%$ & $31.40 \%$ & $100 \%$ \\
\hline
\end{tabular}

Ukupno 60,33\% ispitanika istaklo je da skoro nikada nisu primetili da su postali razrdažljivi ili uznemireni kada pokušavaju da smanje ili prekinu igranje video-igara (v. Tabelu 5), dok se ponekad to dešava svega 13,22\%, skoro uvek samo 9,09\% ispitanih.

Tabela 5. Smanjivanje ili prekidanje igranja video-igara kao impuls za razdražljivost/uznemirenost iz vizure učenika

4. Da li ste primetili da postajete razdražljivi ili uznemireni kada pokušavate da smanjite ili prekinete igranje video-igara?

\begin{tabular}{|l|l|l|l|l|l|l|}
\hline Odgovori & Skoro nikad & Retko & Ponekad & Često & Skoro uvek & Ukupno \\
\hline Broj & 73 & 14 & 16 & 7 & 11 & 121 \\
\hline $\begin{array}{l}\text { Procentualna } \\
\text { zastupljenost }\end{array}$ & $60.33 \%$ & $11.57 \%$ & $13.22 \%$ & $5.79 \%$ & $9.09 \%$ & $100 \%$ \\
\hline
\end{tabular}

Prema mišljenju većine ispitanika (63,64\%) igranje video-igara skoro nikada nije način da se pobegne od problema i loših osećanja (v. Tabelu 6), da se to retko dešava prepoznaje se u samo $14,05 \%$ odgovora, a skoro uvek u $4,13 \%$ odgovora. 
Tabela 6. Igranje video-igara kao beg od svakodnevnice iz perspektive učenika

5. Da li ste koristili igranje video-igara kao način da pobegnete od problema i loših osećanja?

\begin{tabular}{|l|l|l|l|l|l|l|}
\hline Odgovori & Skoro nikad & Retko & Ponekad & Često & Skoro uvek & Ukupno \\
\hline Broj & 77 & 17 & 14 & 8 & 5 & 121 \\
\hline $\begin{array}{l}\text { Procentualna } \\
\text { zastupljenost }\end{array}$ & $63.64 \%$ & $14.05 \%$ & $11.57 \%$ & $6.61 \%$ & $4.13 \%$ & $100 \%$ \\
\hline
\end{tabular}

Bezmalo svi ispitanici $(80,17 \%)$ tvrde da skoro nikada nisu lagali porodicu ili prijatelje o tome koliko vremena igraju video-igre ( $v$. Tabelu 7). Nijedan ispitanik nije istakao da to skoro uvek radi, često to čini $4,13 \%$ ispitanih.

Tabela 7. Mišljenje učenika o 'prikrivanju istine' u vezi sa dužinom i intenzitetom igranja video-igara

6. Da li ste ikada lagali porodicu ili prijatelje o tome koliko vremena igrate video-igre?

\begin{tabular}{|l|l|l|l|l|c|l|}
\hline Odgovori & Skoro nikad & Retko & Ponekad & Često & Skoro uvek & Ukupno \\
\hline Broj & 97 & 12 & 7 & 5 & - & 121 \\
\hline $\begin{array}{l}\text { Procentualna } \\
\text { zastupljenost }\end{array}$ & $80.17 \%$ & $9.92 \%$ & $5.79 \%$ & $4.13 \%$ & - & $100 \%$ \\
\hline
\end{tabular}

U Tabeli 8 pokazano je da polovina ispitanika $(58,58 \%)$ smatra da skoro nikada ne preskače kućne obaveze kako bi više vremena proveli igrajući video-igre, retko to čini $25,62 \%$, a često svega $4,96 \%$.

Tabela 8. Odnos kućnih obaveza i igranja video-igara iz vizure učenika

7. Da li ponekad preskočite kućne obaveze kako bi više vremena proveli igrajući video-igre?

\begin{tabular}{|l|l|l|l|l|l|l|}
\hline Odgovori & Skoro nikad & Retko & Ponekad & Često & Skoro uvek & Ukupno \\
\hline Broj & 71 & 31 & 10 & 6 & 3 & 121 \\
\hline Procenat & $58.68 \%$ & $25.62 \%$ & $8.26 \%$ & $4.96 \%$ & $2.48 \%$ & $100 \%$ \\
\hline
\end{tabular}

Na pitanje Da li preskočite izradu domaćeg zadatka kako biste proveli više vremena igrajući video igre? $74,38 \%$ ispitanika tvrdi da to skoro nikada ne čini, dok je zastupljenost onih koji to čine često i skoro uvek minimalna (0,17\% u oba slučaja), v. Tabelu 9.

Tabela 9. Odnos školskih obaveza i igranja video-igara iz perspektive učenika

8. Da li preskočite izradu domaćeg zadatka kako biste proveli više vremena igrajući video-igre?

\begin{tabular}{|l|l|l|l|l|l|l|}
\hline Odgovori & Skoro nikad & Retko & Ponekad & Često & Skoro uvek & Ukupno \\
\hline Broj & 90 & 21 & 6 & 2 & 2 & 121 \\
\hline $\begin{array}{l}\text { Procentualna } \\
\text { zastupljenost }\end{array}$ & $74.38 \%$ & $17.36 \%$ & $4.96 \%$ & $0.17 \%$ & $0.17 \%$ & $100 \%$ \\
\hline
\end{tabular}

Više od polovine ispitanika $(66,94 \%$, v. Tabelu 10) smatra da skoro nikada nije uradila loše neki školski zadatak jer su bili nepripremljeni budući da su potrošili previše vremena u igranju videoigara, retko se to desilo prema mišljenju svega 14,88\% ispitanika, a ponekad prema zapažanju 9 , $09 \%$ ispitanih.

Tabela 10. Šta o igranju video-igara kao mogućem uzroku loših školskih postignuća misle učenici 9. Da li ste ikada uradili loše neki školski zadatak zbog nepripremljenosti jer ste potrošili previše vremena igrajući video-igre?

\begin{tabular}{|l|l|l|l|l|l|l|}
\hline Odgovori & Skoro nikad & Retko & Ponekad & Često & Skoro uvek & Ukupno \\
\hline Broj & 81 & 18 & 11 & 8 & 3 & 121 \\
\hline $\begin{array}{l}\text { Procentualna } \\
\text { zastupljenost }\end{array}$ & $66.94 \%$ & $14.88 \%$ & $9.09 \%$ & $6.61 \%$ & $2.48 \%$ & $100 \%$ \\
\hline
\end{tabular}


Kako pokazuje Tabela 11, 62,81\% ispitanika skoro nikad ne odlučuje da provede više vremena na internetu nego da izađu napolje sa svojim prijateljima, retko to čini $18,18 \%$, a često svega $3,31 \%$.

Tabela 11. Učenici o društvenim odnosima i igranju video-igara

10. Koliko često odlučujete da provedete više vremena na internetu, nego da izađete van sa svojim prijateljima?

\begin{tabular}{|l|l|l|l|l|l|l|}
\hline Odgovori & Skoro nikad & Retko & Ponekad & Često & Skor uvek & Ukupno \\
\hline Broj & 76 & 22 & 17 & 4 & 2 & 121 \\
\hline Procenat & $62.81 \%$ & $18.18 \%$ & $14.05 \%$ & $3.31 \%$ & $0.17 \%$ & $100 \%$ \\
\hline
\end{tabular}

Analizom procentualne zastupljenosti izabranih odgovora na ponuđenoj skali, a prema svakom pojedinačnom pitanju, utvrđeno je da dominiraju sledeći stavovi ispitanika, odnosno da učenici četvrtog razreda osnovne škole većinom smatraju da:

1. samo ponekad (procentualna zastupljenost odgovora: 30,58\%) više troše vremena razmišljajući o igranju video-igara, učenju taktika za igranje video-igara ili planiranju sledeće prilike za igru;

2. skoro nikada $(33,88 \%)$ nemaju potrebu da provode više vremena kako bi igrali videoigre i osetili uzbuđenje;

3. skoro uvek (31,40\%) pokušavaju da vremenski kraće ili ređe igraju video-igre;

4. skoro nikada $(60,33 \%)$ nisu primetili da su postali razdražljivi ili uznemireni kada pokušavaju da smanje ili prekinu igranje video-igara;

5. skoro nikada $(63,64 \%)$ ne vide igranje video-igara kao način da se pobegne od problema i loših osećanja;

6. skoro nikada $(80,17 \%)$ nisu lagali porodicu ili prijatelje o tome koliko vremena igraju video-igre;

7. skoro nikada $(58,58 \%)$ ne preskaču kućne obaveze kako bi više vremena proveli igrajući video-igre;

8. skoro nikada (74,38\%) ne preskaču izradu domaćeg zadatka kako bi proveli više vremena igrajući video-igre;

9. skoro nikada $(66,94 \%)$ nisu uradili loše neki školski zadatak jer su bili nepripremljeni potrošivši previše vremena u igranju video-igara;

10. skoro nikad $(62,81 \%)$ ne odlučuju da provode više vremena na internetu nego da izađu napolje sa svojim prijateljima.

Dobijeni rezultati potvrđuju našu polaznu hipotezu: Učenici četvrtog razreda osnovne škole ne smatraju da su zavisni od igranja video-igara. Prema mišljenju učenika koja dominiraju, oni nemaju izražene potrebe da provode više vremena u ovakvoj vrsti aktivnosti, nisu primetili kod sebe promenljivo ili problematično ponašanje uzrokovano igranjem video-igara, kao ni fizičke smetnje ako žele da smanje vreme provedeno u igranju ili ga prekinu. Takođe, ispitanici ne smatraju da su narušili socijalne odnose (sa porodicom i prijateljima) ili zanemarili školske i kućne obaveze i interesovanja, što bi, ukupno gledajući, bili neki od signala zavisnosti od igranja video-igara, kao podvrste zavisnosti od interneta.

Sumiranjem dobijenih rezultata, nametnulo se i sledeće pitanje: Da li su ispitanici davali iskrene ili više socijalno prihvatljive/poželjne odgovore? U prilog ovome stoje odgovori, doduše samo na jedno pitanje. Na pitanje br.3 - Da li ste pokušavali da vremenski kraće ili ređe igrate video-igre? - najviše ispitanika odgovorilo je da skoro uvek (31,40\%) pokušava da vremenski kraće ili ređe igra video-igre. Postavlja se pitanje: Zašto je to tako? Zašto ispitanici permanentno pokušavaju da umanje vreme provedeno u igranju video-igara, ako već, prema njihovom mišljenu, ova 
vrsta aktivnosti ne preti da preraste u zavisnost? Ovo zapažanje svakako može poslužiti kao potencijalno polazište za novo istraživanje.

\section{Zaključak}

Verujemo da predstavljeno ispitivanje i dobijeni rezultati nesumnjivo otvaraju polja za buduća promišljanja, podrobnija i obimnija istraživanja izabrane teme, pa i izabranog uzorka. Smatramo da bi dobro bilo dodatno ispitati najpre koliko učenici osnovnih škola, prema sopstvenoj proceni ali i proceni bližeg okruženja, npr. roditelja/staratelja/učitelja, svakoga dana posvećuju vremena u igranju video-igara. lako nije još precizno utvrđeno da li vreme provedeno u igranju video-igara treba posmatrati kao pouzdani simptom zavisnosti od igranja video-igara ili ne, verujemo da bi doprinelo koncipiranju zaokruženije slike o igranju video-igara od strane učenika nižih razreda osnovne škole. Pritom treba obezbediti da učenici tokom ispitivanja daju što iskrenije odgovore. Delimično modelovan upitnik mogli bi paralelno popunjavati kako učenici tako i njihovi roditelji/staratelji i učitelji, što bi omogućilo da se preciznije odredi da li na izabranom uzorku vladaju neki od simptoma zavisnosti od igranja video-igara, a da pojedini učenici možda toga i nisu svesni. Posebno bi zanimljivo bilo pratiti ispitivane učenike i nanovo ih anketirati npr. na kraju osmoga razreda, pa nadalje, tokom srednje škole, te razmotriti aktuelnu (ne)zavisnost od interneta i igranja video-igara. A sve to, svakako će menjati nastavnu praksu i eventualno, ako se potvrdi kroz obimnija istraživanja na obuhvatnijem uzorku, kreirati i odgovarajuće korektivne postupke za lečenje zavisnosti od interneta, posebno od igranja video-igara.

Ovo se čini posebno važnim kada u fokusu imamo savremeni kontekst - samim napretkom informaciono-komunikacionih tehnologija i sve većim zahtevima savremenog doba, aktivnosti koje zahtevaju upotrebu tehnologije povećavaju se svakodnevno, što svakako može da poveća i rizik od pojave nekog od oblika zavisnosti od interneta, kao što je i zavisnost od igranja video-igara. Sa ciljem prevencije i sprečavanja ovog oblika zavisnosti, može se predložiti uspostavljanje interventnih centara, a time osmišljavanje i izrada interventnih planova dobija na značaju (Zorbaz, Ulaz, Kizildag, 2015: 489-497). Važan (pred)uslov za rad ovih centara jeste da su u njima angažovani kvalifikovani stručnjaci i da se rad kreira prema prethodnim opsežnim istraživanjima u praksi. Konačno, interesovanje dece i mladih za tehnologiju i računare treba usmeriti na oblasti poput dizajniranja veb-stranica i prenosa informacija preko interneta, i na taj način preduprediti i/ili umanjiti aktivnosti koje potencijalno sa sobom nose i veliki rizik od razvoja nekog od oblika tehnološke zavisnosti.

\section{Literatura}

Bilic, V., Gjukic, D. i Kirinic, G. (2010). Moguci ucinci igranja racunalnih igrica i videoigara na djecu i adolescente. Napredak 151 (2), 195-213. https://hrcak.srce.hr/file/123286, pristupljeno: 1. 11. 2020.

Block, J. (2008). Doctor: Internet Addiction Should Be Termed a Disease. https://www.netaddictionrecovery.com/doctor-internet-addiction-should-be-termed-adisease/, pristupljeno 6.10. 2020.

Brunborg, G. S., Mentzoni, R. A. \& Froyland, L. R. (2014). Is video gaming, or video game addiction, associated with depression, academic achievement, heavy episodic drinking, or conduct problems? Journal of Behavioral Addictions, 3(1), 27-32. DOI: https://doi.org/10.1556/iba.3.2014.002. 
Carr, N. (2010). The Shallows: What the Internet Is Doing to Our Brains. New York, NY: W. W. Norton, 2010. 276 pp, dostupno i na: https://www.academia.edu, www.daftarche.com, pristupljeno: 20.1. 2020.

Cetverikova, O. (2020). Kako se stvara postcovek, Pecat, 12. januar 2020, razgovor vodio: Vladimir Dimitrijevic, dostupno na: https://www.novosti.rs/vesti/naslovna/reportaze/aktuelno.293.html:840818-Dr-OlgaCetverikova-- Kako-se-stvara-postcovek-1deo, pristupljeno: 31. 1. 2020.

Cheng, H. \& Liu, J. (2020). Alterations in Amygdala Connectivity in Internet Addiction Disorder. Sci Rep 10, 2370 (2020). DOI: 10.1038/s41598-020-59195-w

Di, Z., Gong, X., Shi, J., Ahmed, H. \& Nandi, A. K. (2019). Internet addiction disorder detection of Chinese college students using several personality questionnaire data and support vector machine. Addictive behaviors reports, 10, 100200. DOI: 10.1016/j.abrep.2019.100200.

Festl, R., Scharkow, M. \& Quandt, T. (2013). Problematic computer game use among adolescents, younger and older adults. Addiction, 108(3), 592-599. DOI: 10.1111/add.12016.

Fischer, T. (2011). Ist die pathologische Internetnutzung als eigenstandige Erkrankung im Sinne einer stoffungebundenen Suchterkrankung zu diagnostizieren? Suchttherapie 2011; 12(2): 82-84. DOI: $10.1055 / \mathrm{s}-0031-1275322$.

Gentile (2006). The Video Game Addiction Questionnaire with Families Managing Media https://screenstrong.com/wpcontent/uploads/2017/02/TheVideoGameAddictionQuestionnaireGentile2006.pdf, pristupljeno: 3. 11. 2020.

Gomez-Gonzalvo, F., Molina, P. \& Devis-Devis, J. (2020). Which are the patterns of video game use in Spanish school adolescents? Gender as a key factor. Entertainment Computing 34, 100366 DOI: https://doi.org/10.1016/j.entcom.2020.100366.

Gregory, Ch. (2019). Internet Addiction Disorder - Signs, symptoms, diagnosis, and treatments for those who may be addicted to the Web on their PC or smart phone. PSYCOM. https://www.psycom.net/iadcriteria.html\#symptoms, pristupljeno: 3. 11. 2020.

Griffiths, M. (2017). The psychosocial impact of professional gambling, professional video gaming \& eSports. Casino \& Gaming International, 28, 59-63. https://www.researchgate.net/publication/313117350_The_psychosocial_impact_of_pr ofessional_gambling_professional_video_gaming_and_esports, pristupljeno: 26.10. 2020.

Griffiths, M. D. \& Hunt, N. (1995). Computer game playing in adolescence: Prevalence and demographic indicators. Journal of Community \& Applied Social Psychology, 5, 189-193. DOI: $10.1002 /$ casp.2450050307.

Gu, C., Song, J., Hao, E., Zhou, Z., Gao, C. \& Hu, B. (2018). Effects of real-world and virtual openness and Internet communication on social creativity: A serial mediation analysis. Social Behavior and Personality: An international journal, 46(1), 39-48. DOI: $10.2224 / \mathrm{sbp} .6580$.

Henderson, E. C. (2001). Understanding addiction. Jackson, MI: University Press of Mississippi. https://www.questia.com/library/106835802/understanding-addiction, pristupljeno: 2. 11. 2020.

Kuzmanovic, D., Pavlovic, Z., Popadic, D. i Milosevic, T. (2019). Koriscenje interneta i digitalne tehnologije kod dece i mladih u Srbiji: rezultati istrazivanja Deca Evrope na internetu. Beograd: Institut za psihologiju Filozofskog fakulteta u Beogradu. Beograd: Dosije studio. 
http://dobrinkakuzmanovic.weebly.com/uploads/2/6/4/8/26488972/eu_kids_online_srp oktobar_2019..pdf, pristupljeno: 1. 11. 2020.

Labas, D, Marincic, I. \& Mujcinovic, A. (2019). Percepcija djece o utjecaju videoigara. Communication Management Review, 4 (1). file:///C:/Users/10/Downloads/Labas_Marincic_Mujcinovic.pdf, pristupljeno: 30. 10. 2020.

Lazetic, G., Mladenovic, I. (2014). Izgubljeni u virtulenom svetu. Zavisnost od interneta i video igara. Sa terapijskim prirucnikom. Beograd: Cigoja stampa.

Masi, G., Berloffa, S., Muratori, P., Paciello, M., Rossi, M. \& Milone, A. (2020). Internet addiction disorder in referred adolescents: a clinical study on comorbidity. Addiction Research \& Theory. DOI: 10.1080/16066359.2020.1772242.

Milani, L., La Torre,G., Fiore, M., Grumi, S., Gentile, D. A., Ferrante, M., Miccoli, S. \& Di Blasio, P. (2017). Internet Gaming Addiction in Adolescence: Risk Factors and Maladjustment Correlates. International Journal of Mental Health and Addiction, 16, 888-904. DOI: 10.1007/s11469-017-9750-2.

Plante, C. N., Gentile, D. A., Groves, C. L., Modlin, A. \& Blanco-Herrera, J. (2019). Video games as coping mechanisms in the etiology of video game addiction. Psychology of Popular Media Culture, 8(4), 385-394. DOI: 10.1037/ppmooo0186.

Prensky, M. (2001). Digital Natives, Digital Immigrants. On the Horizon (MCB University Press), 9/5, 1-6. http://skr.rs/56R, pristupljeno 13. 10. 2020.

Prtljaga, P. \& Bratina, T. (2020). Primena informaciono-komunikacionih tehnologija u vaspitnoobrazovnom radu. Vrsac: Visoka skola strukovnih studija za vaspitace „Mihailo Palov”. http://research.rs/Publications/Primena_IKT.pdf, pristupljeno 13.10. 2020.

Prtljaga, P. \& Dordev, I. (2020). „Neophodnost kontinuiranog unapredivanja digitalnih vestina u identifikaciji i radu sa darovitima", U G. Gojkov i A. Stojanovic (ur.): Zbornik 25: Kompleksnost fenomena darovitosti i kreativnosti - izazovi pojedinac i drustvo, 25 (2020) (str. 336-347). Vrsac: Visoka skola strukovnih studija za vaspitace „Mihailo Palov” i Univerzitet,,Aurel Vlajku” (Universitatea de Vest „Aurel Vlaicu”, Arad, Romania).

Prtljaga, P. (2012). Moralne dileme darovitih - od Nobela do Gejtsa. U (G. Gojkov i A. Stojanovic, A., ur.), Zbornik 17, sa XVII okruglog stola „Daroviti i moralnost” (str. 698706). Vrsac: Visoka skola strukovnih studija za obrazovanje vaspitaca „Mihailo Palov”; Arad (Rumunija): Univerzitet „Aurel Vlajku”; Bitolj (Makedonija): Univerzitet „Sv. Kliment Ohridski" - Pedagoski fakultet; Ptuj (Slovenija): REVIVIS - Institut za razvijanje nadarenosti.

Rumpf, H. J., Batra, A. \& Mann, K. (2014). Replik auf die Kommentare zum Editorial „Pathologischer Internetgebrauch: Sucht oder psychosomatische Erkrankung?”. SUCHT (2014), 60, 364-366. DOI: 10.1024/0939-5911.a000338.

Schwab, K. (2016). The Fourth Industrial Revolution. New York: Crown Business. https://www.academia.edu/35846430/The_Fourth_Industrial_Revolution_Klaus_Schwa b, pristupljeno: 20. 9. 2020.

Scimeca, G., Bruno, A., Crucitti, M., Conti, C., Quattrone, D., Pandolfo, G., Zoccali, R. A. \& Anna Muscatello, M. R. (2018). Abnormal illness behavior and Internet addiction severity: The role of disease conviction, irritability, and alexithymia. Journal of Behavioral Addictions. 6/1, p. 92-97.6p. DOI: 10.1556/2006.6.2017.008.

Te Wildt, B.T. (2011) Ist die pathologische Internetnutzung als eigenstandige Erkrankung im Sinne einer stoffungebundenen Suchterkrankung zu diagnostizieren? Suchttherapie 2011; 12(2): 80-82. DOI: 10.1055/s-0031-127532.

Tras, Z. (2019). Internet Addiction and Loneliness as Predictors of Internet Gaming Disorder in Adolescents. Educational Research and Reviews, 14/13, 465-473. https://eric.ed.gov/?id=EJ1222950. DOI: 10.5897/ERR2019.3768. 
Triberti S, Milani L, Villani D, Grumi S, Peracchia S, Curcio G. \& Riva G. (2018). What matters is when you play: Investigating the relationship between online video games addiction and time spent playing over specific day phases. Addict Behav Rep. 2018 Jun 22; 8: 185188. DOI: 10.1016/j.abrep.2018.06.003.

Venkatesh, V., Sykes, T.A, Chan, Frank K. Y., Thong, James Y. L. \& Hu, Paul Jen-Hwa (2019). Children's Internet Addiction, Family-to-Work Conflict, and Job Outcomes: A Study of Parent-Child Dyads. MIS Quarterly. 43 (3). 903-927. DOI: 10.25300/MISQ/2019/12338.

Votson, R. (2016) Buduci umovi: kako digitalno doba menja nas um / preveli: Tijana Mirkovic i Danilo Pusic. Beograd: Plato. https://www.scribd.com/document/370931801/Ri\%C4\%8Dard-Votson-Budu\%C4\%87iumovi-pdf, pristupljeno: 30. 10. 2020. [izvor na cirilici].

Wakefield, M. A. \& Rice, C. J. (2008). The impact of cyber-communication on today's youth (ACAPCD-14). Alexandria, VA: American Counseling Association. https://www.counseling.org/resources/library/ACA\%20Digests/ACAPCD-14.pdf, pristupljeno 12. 10. 2020.

Yeonsoo, K., Jin Young P., Sung Byuk, K., In-Kyung, J., Yun Sook, L. \& Jung-Hyun, K. (2010). The effects of Internet addiction on the lifestyle and dietary behavior of Korean adolescents. Nutrition Research and Practice (Nutr Res Pract) 4(1), 51-57. DOI: 10.4162/nrp.2010.4.1.51.

Young, K. S. (1998). Internet addiction: The emergence of a new clinical disorder. Cyberpsychol Behaviour, 11, 237-244. DOI: 10.1089/cpb.1998.1.237.

Zastrow, M. (2017). News feature: Is video game addiction really an addiction? Proceedings of the National Academy of Sciences, 114(17), 4268-4272. DOI: 10.1073/pnas.1705077114.

Zorbaz, S. D., Ulas, O. \& Kizildag, S. (2015). Relation between Video Game Addiction and Interfamily Relationships on Primary School Students. Educational Sciences: Theory \& Practice, 15 (2), 489-497. DOI: 10.12738/estp.2015.2.2090.

\section{Biografska beleška}

Ivana Mitrović Đorđević je doktor opštih defektoloških nauka. Kao diplomirani logoped defektolog od 1994. godine radi u OŠ „,Dušan Dugalić”, Beograd. Godine 1995. diplomirala je i na drugom smeru i stekla zvanje diplomirani defektolog - surdopedagog. Magistrirala je na Fakultetu za specijalnu edukaciju i rehabilitaciju sa temom: „Mogućnosti socijalne integracije telesno invalidnih lica". Radila je kao koordinator DILS projekta od 2009. do 2012. godine ispred Ministarstva rada i socijalne politike. Koordinator je Centra za zaštitu dece od nasilja na internetu, podržanog od strane Ministarstva trgovine, turizma i telekomunikacija (od 2017. godine). Od 2000. godine aktivno učestvuje kao autor ili koordinator u brojnim internacionalnim projektima koji se bave unapređenjem kvaliteta života stanovništva. Autor je i učesnik projekata koje su podržali: Svetska banka, Handicap international, Save the children, OPTO international AB, SIDA, People in Need, Akademija centralno-evropskih škola (ACES), Razvojna agencija Južnomoravskog regiona, Ministarstvo poljoprivrede na projektima Svetske banke, Ministarstvo za rad i socijalna pitanja, Ministarstvo trgovine, turizma i telekomunikacija, Ministarstvo za razvoj nauke i tehnološkog razvoja. Dr Ivana Mitrović Đorđević do sada je učestvovala na brojnim (inter)nacionalnim konferencijama i predstavljala radove iz oblasti specijalne edukacije i rehabilitacije, logopedije i uže naučne oblasti Poremećaji jezika. 